\title{
Correlation Between the Level of Socio-economic Development and the Use of the Information and Communication Technologies
}

\begin{abstract}
During recent decades, the rate of structural shifts in the world economy has been especially fast. One of the factors used to influence these processes was to actively develop hi-tech industries and information and communication technologies. With the course of time, the level of informatization of society becomes a defining factor for a country's competitiveness and predefines its ability to integrate into the global economy.

The article characterizes the readiness of different countries to make a move to an innovative way of development based on analysis of combined rating tables that contain integral indices of society's informatization level. The level of accomplishment of the task to form an innovative type of economy can be assessed in the link between implementation of science and technology progress achievements (i.e.: through the use of information and communication technologies) and the level of socio-economic development of the world countries. Current positions held by Russia and Poland according to some integral indices are also being analyzed.
\end{abstract}

Key words: information and communication technologies (ICT), level of informatization, global competitiveness, socio-economic development

\section{INTRODUCTION}

Information and communication technologies (ICT), the term encompassing the whole range of technologies that ensure processing, recording and dissemination of information are one of the basic elements of modern economic and social life of the world society. Computerization has embraced virtually all spheres of human activities and has helped to enlarge the information space up to the global scale. Information systems and networks for transmission of information provide for banking and financial activities, functioning of tax systems, statistics, transportation management, industrial enterprises management and a lot of other phenomena (Bukreev 2009). However, being a result of a high technology society, ICTs are the major evidence of socio-economic stratification of the globalizing world and differences in access to the modern achievements of the science and technology progress. 
Subject of the research - correlation between the use of the information and communication technologies and the level of socio-economic development of countries of the world.

Countries having a high level of penetration of ICT achieve greater results in building wealth of their citizens (GDP growth rate per capita). However, this effect can be seen only when a country has reached a certain threshold indicators in use of ICT owing to its socioeconomic development management results.

Purpose of the research - to demonstrate that global penetration of ICT is a driver behind economic growth and development of countries in conditions of globalization.

\section{ICT AND STRUCTURAL SHIFTS IN THE WORLD MANUFACTURING INDUSTRY}

Synergy effect, being a result of active implementation of achievements of science and technology progress multiplied by globalisation effects, leads to steady growth of ICT sector in the global economy. Changes in the structure of branches of the world processing industries towards the development of high-tech industries and manufactures in its turn fosters integration of countries that have embarked on the innovation path into global networks of producing added value as well as into industrial networks owing to accelerated methods of reproduction of technology and faster access to markets.

In the period 1980-2010, the world economy in general as well as the industries of developed countries saw the highest growth rates in the production of communication devices (radio-, TV- and communication equipment), computer and office appliances and electric equipment. Thus, in 1995 the main processing industry sectors were food and beverage manufacturing (11.8\%), as well as chemicals and chemical industry products manufacturing $(10 \%)$. However, on the wave of sharp growth of demand in the world market of communication devices, their share rose four times (from 5.6 to 20.7\%) by 2010, bringing these products to the leading positions among the branches within the world manufacturing sector (UNIDO 2011).

Such trends in the global economy were first of all determined by structural shifts in the developed countries' industrial sectors: the share of radio-, TV- and communications equipment as a sum of produced added value reached $27,1 \%$ by 2010 . Currently, the major producers of high-tech products of all kinds are the USA, the European Union countries, China and Japan. In 2010 they held the following shares in the world high-tech production: USA $(27.7 \%$ of the global output, in terms of current prices, in millions of US dollars), China (about 19\%), Japan (about 13\%), Germany (5.5\%), South Korea (4\%), Taiwan (4\%), Great Britain (3\%), France (3\%). Just to add, all European Union countries produced 1/5th of the global output ${ }^{1}$.

In the group of developing countries, whose share of communication devices in the total volume of produced added value rose up to $10.2 \%$ in 2010 , the most intense processes of structural transformation in the industry have been taking place in the past decade in China,

${ }^{1}$ Calculated by: National Science Board. (2012). Science and Engineering Indicators 2012. Arlington, VA: National Science Foundation. Retrieved from: http://www.nsf.gov/ 
Mexico, Brazil, India and the Asian newly industrialized countries (NICs) of the "first" and "second wave" (Rodionova 2012).

\section{ICT AND THE STRUCTURE OF WORLD EXPORTS}

The leading position in the world rankings in terms of export of high technology products (which include the following five industries: 1) aerospace, 2) pharmaceuticals, 3) office and computing, 4) equipment, communications, 5) equipment, scientific instruments), developed countries are still highly ranked, especially if we consider the interregional trade among the countries of the EU. It is noteworthy, however, that the first place in high-tech exports is held by China (23.7\%), which has outstripped the U.S., Germany and Japan. Even if we exclude trade between China and Hong Kong, China's share is still above 17\%, which is equal to the volume of trade in high-tech goods among all 27 EU countries. Asian NICs account for significant amount of world exports of high-tech products too.

Tab. 1. Exports of high-technology goods by region/country/economy, 1995-2010 (\%)

\begin{tabular}{|l|r|r|r|c|}
\hline \multicolumn{1}{|c|}{ Region/country/economy } & 1995 & 2000 & 2005 & 2010 \\
\hline World & 100.0 & 100.0 & 100.0 & 100.0 \\
\hline $\begin{array}{l}\text { World excluding intra-EU } \\
\text { and intra-China/Hong Kong }\end{array}$ & 80.0 & 80.1 & 77.8 & 76.4 \\
\hline EU (total) & 31.1 & 30.0 & 31.0 & 28.9 \\
\hline China and Hong Kong (total) & 6.9 & 8.5 & 18.2 & 23.7 \\
\hline United States & 17.0 & 17.2 & 11.5 & 11.6 \\
\hline Germany & 7.5 & 7.5 & 8.0 & 7.5 \\
\hline Taiwan & 4.1 & 5.0 & 5.3 & 5.7 \\
\hline Japan & 14.7 & 10.4 & 7.0 & 5.0 \\
\hline Singapore & 6.8 & 5.3 & 5.1 & 4.9 \\
\hline South Korea & 4.2 & 4.6 & 4.8 & 4.7 \\
\hline
\end{tabular}

Calculated by: National Science Board. (2012). Science and Engineering Indicators 2012. Arlington, VA: National Science Foundation. Retrieved from: http://www.nsf.gov/

Having introduced a qualitatively new level of production, China is gradually winning over not only the leading positions in its traditional "cheap exports," but also in trade in high added value products. In 2009 it surpassed Germany, the former leader in world export of goods, for the first time, and has moved to the first place in the world export and export of machinery and electronic (\$1 577.6 bn and $\$ 902.6$ bn respectively in 2011). In other words, this type of product already reached almost $60 \%$ of China's total export (World Trade Organization, 2012). And it should be noted that China's exports of ICT goods is growing particularly rapidly: only between 1995 and 2008, it increased twelvefold ${ }^{2}$.

${ }^{2}$ Calculated by: National Science Board. (2012). Science and Engineering Indicators 2012. Arlington, VA: National Science Foundation. Retrieved from: http://www.nsf.gov/ 


\section{ICT AND THE LEVEL OF INFORMATIZATION OF SOCIETY}

By the end of the first decade of the $21^{\text {st }}$ century geographical contrasts in the distribution of the different ICT significantly smoothed: the "digital gap" in the mobile communication industry decreased 16 times, and the scale of penetration of the Internet increased 9 times (Nagirnaya 2012). However, while the quantitative imbalances did decrease, the qualitative ones persisted, supporting the "digital monopoly" of developed countries.

In the network economy, characterized by an increase in the share of digital commerce and the accompanying restructuring of distribution chains, and the growing role of the "e" part of the financial sphere, alongside with modernization of production control systems, etc., the use of ICT is a guarantee of sustainable development in a given country ensuring its economic growth and effective integration into the global economy. In this context, the level of informatization plays the role of one of the most important indicators of a country's competitiveness (Rodionova, Gordeeva 2011).

Currently, various international economic organizations offer some comprehensive indicators that characterize the level of development of knowledge economy. Among them we would like to mention: Knowledge Economy Index - KEI (calculated by the World Bank), Networked Readiness Index - NRI (calculated by the World Economic Forum), Global Innovation Index - GII (calculated by the International business school INSEAD), ICT Development Index (calculated by the International Telecommunication Union). These integral indices not only evaluate the readiness of a country to participate in the information world, but they actually show the basis of the differences existing between countries in the extent of the use of ICT.

While working on this study we calculated correlation coefficients and revealed high direct correlation between each and every of the above-noted indices, and a direct correlation between the index values and the following indicators: GDP per capita, real GDP per $1 \mathrm{em}-$ ployed person, value added of high-tech and ICT industries per capita.

The calculated correlation (data for 2009-2010) between the values of all indices and the GDP per capita in the world countries was in the range of $0,86-0,93$; between indices and real GDP per 1 employed person - in the range of $0,80-0,85$; between the values of the indices and data on the volume of high-tech industries production per capita - in the range of $0,57-0,67$; between the values of the indices and data on the volume of ICT-production per capita - in the range of $0,76-0,84$. This shows, firstly, the high representativeness of the given integral indices, and secondly, that at the present time the only countries that are prepared to the development of the network economy (economy based on knowledge and wide use of ICT) are those which have the highest level of social and economic development. Finally, it points out that the leaders in the production of high-tech products are precisely those countries that have put knowledge and ICT at the service of the economy, and thus they now occupy leading positions in the world economy owing to this fact. 


\section{COMPARISON OF CURRENT INFORMATIZATION LEVELS OF SELECTED COUNTRIES}

Let us separately evaluate the level of informatization in Russia and other post-socialist countries, including Poland. The following are sample data on the Knowledge Economy Index and its components, which illustrate the ability of countries to create, receive, and disseminate knowledge (Tab. 2).

Tab. 2. The Knowledge Economy Index (KEI) and its components by selected countries, 2012

\begin{tabular}{|c|l|c|c|c|c|c|}
\hline \multirow{2}{*}{ Rank } & \multirow{2}{*}{ Country } & \multirow{2}{*}{ KEI } & \multicolumn{4}{|c|}{ Pillars indexes of KEI } \\
\cline { 4 - 7 } & & & $\begin{array}{c}\text { Economic } \\
\text { and institutional regime }\end{array}$ & Innovation & Education & \multirow{2}{*}{ ICT } \\
\hline 1 & Sweden & 9.43 & 9.58 & 9.74 & 8.92 & 9.49 \\
\hline 2 & Finland & 9.33 & 9.65 & 9.66 & 8.77 & 9.22 \\
\hline 3 & Denmark & 9.16 & 9.63 & 9.49 & 8.63 & 8.88 \\
\hline 4 & Netherlands & 9.11 & 8.79 & 9.46 & 8.75 & 9.45 \\
\hline 5 & Norway & 9.11 & 9.47 & 9.01 & 9.43 & 8.53 \\
\hline & & & & & & \\
\hline 26 & Czech Rep. & 8.14 & 8.53 & 7.90 & 8.15 & 7.96 \\
\hline 27 & Hungary & 8.02 & 8.28 & 8.15 & 8.42 & 7.23 \\
\hline 28 & Slovenia & 8.01 & 8.31 & 8.50 & 7.42 & 7.80 \\
\hline 38 & Poland & 7.41 & 8.01 & 7.16 & 7.76 & 6.70 \\
\hline$\ldots$ & & & & & & \\
\hline 55 & Russia & 5.78 & 2.23 & 6.93 & 6.79 & 7.16 \\
\hline
\end{tabular}

Source: The World Bank Group. (2012). KEI and KI Indexes. Knowledge Assessment Methodology 2012. Retrieved from: http://www.worldbank.org/kam/

Analysis of the data presented in the table allows us to evaluate the positions held by Russia and Poland in the world ranking as not very high $\left(38^{\text {th }}\right.$ and $55^{\text {th }}$ out of 145 possible, respectively), and to identify their positions compared to other countries according to integrative index elements (including such important ones as innovation, education, information and communication technologies). In the rating Poland is bypassed by the Czech Republic (the $26^{\text {th }}$ position), Hungary and Slovenia. Russia lags behind even some countries of Central and Eastern Europe, including Slovakia, Croatia, Romania, Bulgaria and Serbia. However, many CIS countries have settled in the table at even lower positions (from $56^{\text {th }}$ in Ukraine the down to the $106^{\text {th }}$ for Tajikistan). The following components of the index have particularly low indicators for Russia and other CIS countries: the institutional regime, innovation, and use of information technology (ICT).

A close link between the widespread introduction of information and communication technologies and the economic prosperity of the state was mentioned during the World Economic Forum back in 2001. Every year since, the countries have been ranked by the Networked Readiness Index - NRI, which consists of a 7-point scale of evaluation. Let us characterize the positions taken by leading countries, the fastest growing countries in Eastern Europe, and Russia (Tab. 3). 
It should be noted that in the table of ranks, according to NRI compared with the rating for 2009, some changes have taken place. The number of countries analyzed increased from 134 in 2009 to 142 in 2012. The group of leaders has shown only minor rearrangements. However, the United States moved from the $3^{\text {rd }}$ to the $8^{\text {th }}$ position. Singapore has gone two positions up, and has come $2^{\text {nd }}$ after Sweden.

Tab. 3. Networked Readiness Index (NRI) by selected countries, 2009-2012

\begin{tabular}{|c|c|c|c|c|c|}
\hline \multicolumn{3}{|c|}{2009} & \multicolumn{3}{|c|}{2012} \\
\hline Rank & Country & NRI & Rank & Country & NRI \\
\hline 1 & Denmark & 5.85 & 1 & Sweden & 5.94 \\
\hline 2 & Sweden & 5.84 & 2 & Singapore & 5.86 \\
\hline 3 & United States & 5.68 & 3 & Finland & 5.81 \\
\hline 4 & Singapore & 5.67 & 4 & Denmark & 5.70 \\
\hline 5 & Switzerland & 5.58 & 5 & Switzerland & 5.61 \\
\hline \multicolumn{6}{|c|}{. } \\
\hline 31 & Slovenia & 4.57 & 37 & Slovenia & 4.62 \\
\hline 32 & Czech Rep. & 4.53 & 42 & Czech Rep. & 4.33 \\
\hline 41 & Hungary & 4.28 & 43 & Hungary & 4.30 \\
\hline 69 & Poland & 3.80 & 49 & Poland & 4.16 \\
\hline \multicolumn{6}{|c|}{$\ldots$} \\
\hline 74 & Russia & 3.77 & 56 & Russia & 4.02 \\
\hline
\end{tabular}

Source: World Economic Forum. (2012). The Global Information Technology Report 2012. Geneva, Switzerland: Author. Retrieved from: http://www.weforum.org/

Attention is drawn to the significant strengthening of the position of Poland, which has come up from the $69^{\text {th }}$ to the $49^{\text {th }}$ place. Among the CIS countries, Kazakhstan moved up from $73^{\text {th }}$ to $55^{\text {th }}$ place, still slightly ahead of Russia, which is currently on the $56^{\text {th }}$ position (up from the $74^{\text {th }}$ place in 2009). However, China is ahead of all CIS countries in the ranking table, holding the $51^{\text {st }}$ position.

A wide use of ICT and implementation of innovations are mutually determining processes. They stimulate increased productivity and business activity that contribute to economic diversification and determine the economy's competitiveness. Global Innovation Index takes into account not only the effectiveness of the knowledge economy, but also assesses the conditions for its successful development, such as policy of the state that encourages innovation, the level of education and research spending, business interest in investing in research and development, etc. (Tab. 4).

Over the past few years, a number of post-socialist countries have significantly improved their positions according to these indicators, rising up in the ranking tables. This is especially true for Russia that has "jumped" over more than ten points. However, its position is still quite low given the potential for development. Thus, in 2012, both Poland and Russia were surpassed in this ranking by the United Arab Emirates (the $37^{\text {th }}$ ), Chile (the $39^{\text {th }}$ ), Bahrain (the $41^{\text {st }}$ place) and some other developing countries. 
Tab. 4. Global Innovation Index (GII) by selected countries, 2009-2012

\begin{tabular}{|c|l|c|c|l|c|}
\hline \multicolumn{2}{|c|}{ Country } & GII & Rank & \multicolumn{1}{c|}{ Country } & GII \\
\hline Rank & \multicolumn{1}{|c|}{ Cout2 } & 68.2 \\
\hline 1 & Iceland & 4.86 & 1 & Switzerland & 64.8 \\
\hline 2 & Sweden & 4.85 & 2 & Sweden & 63.5 \\
\hline 3 & Hong Kong (China) & 4.83 & 3 & Singapore & 61.8 \\
\hline 4 & Switzerland & 4.82 & 4 & Finland & 61.2 \\
\hline 5 & Denmark & 5 & United Kingdom & 49.9 \\
\hline \multicolumn{7}{|l|l|}{} & 49.7 \\
\hline 26 & Slovenia & 3.80 & 26 & Slovenia & 40.7 \\
\hline 27 & Czech Rep. & 3.77 & 27 & Czech Rep. & 40.7 \\
\hline 45 & Croatia & 3.28 & 42 & Croatia & 40.4 \\
\hline 47 & Poland & 3.28 & 42 & Bulgaria & 37.9 \\
\hline 49 & Bulgaria & 3.26 & 44 & Poland & \\
\hline \multicolumn{7}{|l|}{} \\
\hline 64 & Russia & 3.03 & 51 & Russia & \\
\hline
\end{tabular}

Source: INSEAD and WIPO. (2012). The Global Innovation Index 2012: Stronger Innovation Linkages for Global Growth. Fontainebleau, France and Geneva, Switzerland: Authors. Retrieved from: http://www.wipo.int/

Finally, ICT Development Index, which is calculated by the International Telecommunication Union, based on 11 indicators of the population's access to ICT and the extent and effectiveness of their use, reflects directly the degree of penetration of ICT in the economy of the world. In the report for 2012, which provides data on 155 countries for the previous two years, Russia and Poland perform as follows (Tab. 5).

Tab. 5. ICT Development Index (ICT-DI) by selected countries, 2010-2011

\begin{tabular}{|c|c|c|c|c|c|}
\hline \multicolumn{3}{|c|}{2010} & \multicolumn{3}{|c|}{2011} \\
\hline Rank & Country & ICT-DI & Rank & Country & ICT-DI \\
\hline 1 & South Korea & 8.45 & 1 & South Korea & 8.56 \\
\hline 2 & Sweden & 8.21 & 2 & Sweden & 8.34 \\
\hline 3 & Denmark & 8.01 & 3 & Denmark & 8.29 \\
\hline 4 & Iceland & 7.96 & 4 & Iceland & 8.17 \\
\hline 5 & Finland & 7.89 & 5 & Finland & 8.04 \\
\hline \multicolumn{6}{|c|}{$\ldots$} \\
\hline 29 & Italy & 6.13 & 29 & Italy & 6.28 \\
\hline 30 & Poland & 6.09 & 31 & Poland & 6.19 \\
\hline 33 & Czech Rep. & 5.89 & 32 & Czech Rep. & 6.17 \\
\hline \multicolumn{6}{|c|}{$\ldots$} \\
\hline 39 & Slovakia & 5.63 & 37 & Portugal & 6.05 \\
\hline 40 & Russia & 5.61 & 38 & Russia & 6.00 \\
\hline 41 & Croatia & 5.54 & 39 & Slovakia & 5.86 \\
\hline
\end{tabular}

Source: International Telecommunication Union. (2012). Measuring the Information Society 2012. Geneva, Switzerland: Author. Retrieved from: http://www.itu.int/ 
It is evident that the group of leaders hasn't seen any major rearrangements, only the actual values of the index have grown - which indicates the strength of the positions held by these countries. What is thus noteworthy is that the first place is held by an Asian NIC of the "first wave" - South Korea, ahead of highly-developed Western European states. Poland has lost a few positions, but still it has let only Estonia and Slovenia go forward, the only two Central and Eastern European countries (holding the $24^{\text {th }}$ and $25^{\text {th }}$ places, respectively).

As for Russia, compared to the ratings on other leading indicators given above, it confidently holds the $38^{\text {th }}$ place, improving its position by 2 points for a year (from the $40^{\text {th }}$ place in 2010). Russia has not only significantly outstripped other CIS countries (among them the highest, the $46^{\text {th }}$, place, belongs to Belarus), but also many Eastern European countries (Slovakia, Hungary, Croatia, Bulgaria, Romania, etc.)

\section{ICT AND GLOBAL COMPETITIVENESS}

The Global Competitiveness Index (GCI) is calculated for 139 countries, where the rates of the integral index are positioned in the range of 1 to 7 (the index characterizes three main points: the basic requirements, efficiency enhancers and innovation and sophistication factors). The World Economic Forum defines competitiveness as the set of institutions, policies and factors defining the country's level of productivity. It is highlighted that the countries that are more competitive can provide a higher level of income for their citizens. What is important is the information about the components of the Global Competitiveness Index and the positions of Russia and Poland in the international ranking for each of the analyzed positions.

GCI is composed of 113 variables (12 addends) that give a detailed characteristic of competitiveness of countries. It is important to note that no factor taken separately can improve or ensure high competitiveness of the economy of a country. Thus, the effect of increasing expenditures on education can be reduced, for example, due to the ineffectiveness of the labor market, etc. Alternatively, there will be no good results, if graduates do not enjoy opportunities to be properly employed. Attempts to optimize the control of public finances will be successful only if there is no corruption, financial management is transparent and so on. It is important to consider the fact that businesses will invest in research and development and will introduce new technologies into production chains only if the potential profit exceeds the required investment, etc.

Let us compare the positions of the two countries on the basis of ratings on The Global Competitiveness Index true for 2010 and 2012. Thus, in the rating on GCI for 2010-2011 Russia took the $63^{\text {rd }}$ place. Poland had a higher position - the $39^{\text {th }}$. It should be noted that according to the average index of GCI both countries lag behind OECD countries (within a 7-point scale OECD countries' index is 4.9, Russia's - 4.2, and Poland's - 4.5). Before the global financial crisis there had been some improvement of indicators' values (compared with an estimate of the countries' places in the 2008 ranking), but in the post-crisis period positions of our countries slightly declined. Thus, according to the Global Competitiveness Report 
2011-2012, Poland has only the $41^{\text {st }}$ place in the rating of GCI, while Russia has moved from the $63^{\text {rd }}$ to the $66^{\text {th }}$ position. At the beginning of the rating table, that is, in the leaders group there are Switzerland, Singapore, Sweden, Finland, the USA, Germany and other developed countries. It is important to note that China has moved to the $26^{\text {th }}$ place, close to the Republic of Korea (the $24^{\text {th }}$ position). Both these states are far ahead of both Russia and Poland according to many of the analyzed parameters.

Tab. 6. Components of the Global Competitiveness Index (GCI) for Russia and Poland, 2010-2011

\begin{tabular}{|l|c|c|c|c|}
\hline \multirow{2}{*}{ Pillars of GCI } & \multicolumn{2}{c|}{ Russia } & \multicolumn{2}{c|}{ Poland } \\
\cline { 2 - 5 } & Rank & Index & Rank & Index \\
\hline GCI 2010-2011 & 63 & 4.2 & 39 & 4.5 \\
\hline Basic requirements & 65 & 4.5 & 56 & 4.7 \\
\hline $1^{\text {st }}$ pillar: Institutions & 118 & 3.2 & 54 & 4.2 \\
\hline $2^{\text {nd }}$ pillar: Infrastructure & 47 & 4.5 & 72 & 3.8 \\
\hline $3^{\text {rd }}$ pillar: Macroeconomie stability & 79 & 4.5 & 61 & 4.7 \\
\hline $4^{\text {th }}$ pillar: Health and primary education & 53 & 5.9 & 39 & 6.1 \\
\hline Efficiency enhancers & 53 & 4.2 & 30 & 4.6 \\
\hline $5^{\text {th }}$ pillar: Higher education and training & 50 & 4.6 & 26 & 5.0 \\
\hline $6^{\text {th }}$ pillar: Goods market efficiency & 123 & 3.6 & 45 & 4.4 \\
\hline $7^{\text {th }}$ pillar: Labor market efficiency & 57 & 4.5 & 53 & 4.6 \\
\hline $8^{\text {th }}$ pillar: Financial market sophistication & 125 & 3.2 & 32 & 4.7 \\
\hline $9^{\text {th }}$ pillar: Technological readiness & 69 & 3.6 & 47 & 4.0 \\
\hline $10^{\text {th }}$ pillar: Market size & 8 & 5.7 & 21 & 5.1 \\
\hline Innovation and sophistication factors & 80 & 3.4 & 50 & 3.8 \\
\hline $11^{\text {th }}$ pillar: Business sophistication & 101 & 3.5 & 50 & 4.2 \\
\hline $12^{\text {th }}$ pillar: Innovation & 57 & 3.2 & 54 & 3.3 \\
\hline
\end{tabular}

Source: World Economic Forum. (2011). The Global Competitiveness Report 2011-2012. Geneva, Switzerland: Author. Retrieved from: http://www.weforum.org/

The main strengths of Russia and Poland are associated with high rates of primary education and the percentage of the population with secondary and higher education. The most characteristic feature of the Russian economy is availability of wide range of natural resources. Thus, for Russia the problem of the development of the institutional environment is among the tasks that need to be solved in order to upgrade competitiveness. Financial markets lag behind the level of OECD countries, both in terms of efficiency and in terms of reliability. Competitiveness of companies in Russia and Poland is also lower than in developed countries. Alongside with that, the key issues for doing business in Russia are: corruption, access to funding, tax law, crime, inefficiency of the state apparatus, level of taxation, low-skilled labor, poor labor ethics, inadequate infrastructure, etc. As for Poland, the following issues are of greater importance: tax legislation and the inefficiency of the state apparatus, labor law, access to funding, taxation problems. In general, a more profound and detailed study of all components of the Global Competitiveness Index, on the country-by-country basis is needed. 


\section{CONCLUSION}

In conclusion, we would like to once again highlight the following: ICTs play an increasingly important role in the global economy. The so-called "digital gap", which describes the gap between the poorest countries and the richest ones in terms of volume and quality of these technologies, is gradually closing. The countries that have managed to take advantage of the globalization of world markets for high-tech production, widely implement the latest technologies and ICT in the process of socio-economic development, these countries are now enjoying the most impressive results.

Thus, such things as investment in ICT and liberal policy of telecommunications openness are of great importance for the growth of competitiveness of the economies in transition. Innovative development is the key to strengthening the economic power at all levels of production. Implementation of an effective innovation and investment policies will allow Russia and Poland to take a more worthy place in the global economy in the post-crisis period and in the future.

Questions about the development of new and modernization of existing instruments and mechanisms for the introduction of innovative technologies in industrial production, about how to increase innovation activities of organizations, on the state support of high-tech sector, on fundraising and promotion of high technology products made in Russia, Poland and other Eastern European countries to the world market retain their high relevance. By identifying the positions of Russia and Poland in the world rankings, first of all according to the indicators characterizing the use of modern information and communication technologies, it is important to determine what should be done to make our countries closer to the leading economies by working out our own innovation paradigm of national development.

\section{References}

Bukreev, I.N. (2009). Russia moves into the information society. Information Society: [electronic version], 3. Retrieved from: http://emag.iis.ru/arc/infosoc/emag.nsf/BPA/ d2519f9007348f$19 \mathrm{c} 32576770050 \mathrm{c} 877$

INSEAD and WIPO. (2012). The Global Innovation Index 2012: Stronger Innovation Linkages for Global Growth. Fontainebleau, France and Geneva, Switzerland: Authors. Retrieved from: http:// www.wipo.int/

International Telecommunication Union. (2012). Measuring the Information Society 2012. Geneva, Switzerland: Author. Retrieved from: http://www.itu.int/

Nagirnaya, A. (2012). Global patterns in expansion of ICT (the $20^{\text {th }}$ - the beginning of the $21^{\text {st }}$ century). Abstract of the thesis for the degree of Candidate of Geographical Sciences. Moscow. Printed as manuscript.

National Science Board. (2012). Science and Engineering Indicators 2012. Arlington, VA: National Science Foundation. Retrieved from: http://www.nsf.gov/

Rodionova, I.A., Gordeeva, A.S. (2011). The role of information technologies at the economic development of countries. Issues of innovation economics, 7(7), 18-26. Retrieved from: http://www. creativeconomy.ru/en/articles/14564/ 
Rodionova, I. (2012). World manufacturing industry: structural and spatial shifts. Annals of the University of Bucharest - Geography Series, 55-67. Retrieved from: http://www.annalsreview. geo.unibuc.ro/2012/Rodionova.pdf

The World Bank Group. (2012). KEI and KI Indexes. Knowledge Assessment Methodology 2012. Retrieved from: http://www.worldbank.org/kam/

UNIDO. (2011). Industrial Development Report 2011. Vienna, Austria: Author. Retrieved from: http:// www.unido.org/

World Economic Forum. (2011). The Global Competitiveness Report 2011-2012. Geneva, Switzerland: Author. Retrieved from: http://www.weforum.org/

World Economic Forum. (2011). The Russia Competitiveness Report 2011. Geneva, Switzerland: Author. Retrieved from: http://www.weforum.org/

World Economic Forum. (2012). The Global Information Technology Report 2012. Geneva, Switzerland: Author. Retrieved from: http://www.weforum.org/

World Trade Organization. (2012). International trade statistics 2012. Geneva, Switzerland: Author. Retrieved from: http://www.wto.org/

Irina A. Rodionova, Doctor of Geographical Sciences, Professor, Chair of Regional Economics and Geography, Peoples' Friendship University of Russia, Department of Economics.

Research Interests: socio-economic geography of the world and Russia, the world industry, an innovative economy and human resource, international tourism, the regional economy.

She has created a series of monographs and scientific articles about the structural shifts and trends of development of the world industry, as well as about the structural shifts in Russian economy (including published in the journals in the database SCOPUS, VERSITA).

Textbooks on the economic geography of the world and Russia to graduate high school and university students used in Russia, the Republic of Kazakhstan, the Republic of Belarus, Ukraine, Lithuania, Azerbaijan, Uzbekistan, Poland, Serbia, Bulgaria, Romania, etc.

A member of the editorial board of scientific journals: "Bulletin of Geography. Socio-economic Series" - Poland; "Bulletin of the Al-Farabi Kazakh National University. Geographic series". Almaty Kazakhstan, "Bulletin of People's Friendship University of Russia. Economy Series" - Russia.

Uliana V. Mizerovskaya, $\mathrm{PhD}$ in Economics, Associate Professor, Chair of Regional Economics and Geography, Peoples' Friendship University of Russia, Department of Economics.

Mizerovskaya Uliana was granted with $\mathrm{PhD}$ degree in Economics in 2009 for her research of integration organizations in CIS-countries. Since then, her scientific interests have concerned economic development of post-socialist countries. In her studies she looked at the factors catalyzing development of the said countries including external ones (such as regional integration and participation in other international activities) and internal ones (such as using of ICT which is a subject of the present article).

adres/address: Peoples' Friendship University of Russia,

Department of Economics, 117198, ul. Miklukho-Maklaya, 6, Moscow, Russia

e-mail: iarodionova@mail.ru (Rodionova Irina A.),ouliana-m@yandex.ru (Mizerovskaya Uliana) 